\title{
Muhasebe Meslek Mensupları ile Vergi Mükelleflerinin Karşılaştıkları Sorunlar ve Çözüm Önerileri: Vergi Uyumuna iliş̧kin Bir İnceleme ${ }^{1}$
}

\section{The Problems Faced and Solution Proposals by Accounting Professionals and Taxpayers: A Review on Tax Compliance}

Arş. Gör. Dr. Aytül Bişgin² - Dr. Öğr. Üyesi Sema Ünlüer ${ }^{3}$ - Prof. Dr. M. Erkan Üyümez ${ }^{4}$

Başvuru Tarihi: 24.08.2019

Kabul Tarihi: 30.12.2019

Öz

Bu araştırmada muhasebe meslek mensuplarının mesleki yaşantılarında karşılaştıkları sorunlar ile mükelleflerin iş yaşantılarında karşılaştıkları sorunların neler olduğu ve bu sorunlara ilişkin çözüm önerilerinin vergi uyumunu nasıl etkilediği tespit edilmeye çalışılmıştır. Bu amaç doğrultusunda araştırma, nitel araştırma yöntemi yardımıyla gerçekleştirilmiş ve durum çalışması olarak desenlenmiştir. Araştırma verileri 25 muhasebe meslek mensubu ve 15 vergi mükellefi ile yapılan yarı yapılandırılmış görüşmeler aracılığıyla toplanmıştır. Araştırma verilerinin analizi, tümevarm analizi yoluyla bilgisayar destekli nitel veri analizi programından biri olan NVivo 11 Pro yardımı ile gerçekleştirilmiştir. Araştırmanın bulguları ise araştırma sorusu çerçevesinde sunulmuş ve bu bulgular vergi uyumu bağlamında değerlendirilmiştir.

Anahtar Kelimeler: Vergi Uyumu, Muhasebe Meslek Mensupları, Vergi Mükellefleri, Nitel Araştırma Yöntemi, Sorunlar

\begin{abstract}
In this study, it was tried to determine the problems faced by accounting professionals in their professional lives and the problems faced by taxpayers in their business life and how the solution proposals for these problems affect the tax compliance. For this purpose, the research was carried out with the help of qualitative research method and it was designed as case study. Research data were collected through semi-structured interviews with 25 accounting professionals and 15 taxpayers. Analysis of the research data was carried out with the help of NVivo 11 Pro, one of the computer-aided qualitative data analysis programs through induction analysis. The findings of
\end{abstract}

\footnotetext{
${ }^{1}$ Bu çalışma Anadolu Üniversitesi Sosyal Bilimler Enstitüsü Maliye Anabilim Dalı’nda Prof. Dr. M. Erkan Üyümez ve Dr. Öğr. Üyesi Sema Ünlüer danışmanlığında Aytül Bişgin tarafından “Türkiye'de Muhasebe Meslek Mensupları ile Mükellefler Arasında Gerçekleşen Etkileşimlerin Vergi Uyumu Bağlamında İncelenmesi” ismiyle tamamlanarak 10.08.2018 tarihinde savunulan doktora tezinden türetilmiştir.

${ }^{2}$ Karamanoğlu Mehmetbey Üniversitesi, İİB, Maliye Bölümü, aytulbisgin@gmail.com, ORCID: 0000000324883541

${ }^{3}$ Anadolu Üniversitesi, Engelliler Entegre Yüksekokulu, semaaktas@anadolu.edu.tr, ORCID: 0000000329589798

${ }^{4}$ Anadolu Üniversitesi, İİB, Maliye Bölümü, meuyumez@anadolu.edu.tr, ORCID: 0000000175673486
} 
the study were presented within the framework of the research question and these findings were evaluated in the context of tax compliance.

Keywords: Tax Compliance, Accounting Professionals, Taxpayers, Qualitative Research Methodology, Problems

\section{Giriş}

Vergi uyumu vergi mükelleflerinin vergi kanunlarına uyum göstermesidir (James and Alley, 2002). Dolayısıyla devletin en önemli gelir kaynağı olan vergilerin mükellefler tarafından zamanında ve ilgili yasalara uygun olarak ödenebilmesi, diğer yükümlülüklerin yerine getirilmesi mükelleflerin vergiye uyum göstermelerine bağlıdır. Yasaların skk aralıklarla değişikliğe uğramasından dolayı takibinin zor olması, vergi kanunlarının sadelikten uzak olması nedeniyle doğru anlaşılmama riskini taşıması, vergi avantajlarından yararlanma isteği, vergi ile ilgili teknik konularda bilgi eksikliği ve kanun boşluklarından yararlanarak daha az vergi ödeme isteği gibi nedenlerden dolayı mükellefler genellikle bir desteğe ihtiyaç duyarlar. $\mathrm{Bu}$ destek hizmetini ise serbest muhasebeci mali müşavirler ile gerek serbest çalşsan gerek bağımsız denetim kuruluşlarına bağlı olarak çalışan yeminli mali müşavirler vermektedir.

Muhasebe meslek mensupları ile vergi mükellefleri arasındaki bu ilişkinin olağan sürecinde ise hem muhasebe meslek mensupları hem de vergi mükellefleri birtakım sorunlarla karşı karşıya kalmaktadır. Bu sorunlar muhasebe meslek mensupları ile vergi mükellefleri arasındaki iş ilişkisinden kaynaklanabildiği gibi vergilendirme sürecinde muhatap oldukları kişi ya da kurumlardan da kaynaklanabilmektedir.

Literatürde yer alan çalışmalara bakıldığında; Kalaycı ve Tekşen (2006) tarafından yapılan çalı̧̧mada Isparta il merkezinde 52 muhasebe meslek mensubuna (SM, SMMM, YMM) yüz yüze görüşme suretiyle uygulanan bir anketle, muhasebecilik mesleğinde karşılaşılan sorunlar ve meslek mensuplarının istek, görüş ve önerileri tespit edilmeye çalı̧ılmıştır. Çalışma sonucunda ise muhasebecilerin karşılaştıları sorunlardan bazıları: Mükellefler tarafından en iyi muhasebecinin en az vergi ödeten muhasebeci olarak görünmesi, meslek mensuplarının genellikle her gün kanunlarda yapılan değişiklikleri takip edememesi, ankete katılan meslek mensuplarının büyük bir çoğunluğu meslektaşları tarafından ucuz defter tutulduğunu ve iş yükünün çok fazla olduğunu belirtmiştir.

Gökgöz ve Zeytin (2012) tarafından yapılan çalışmada Bilecik ve Yalova illerinde faaliyet gösteren muhasebe meslek mensuplarının mesleklerini icra ederken karşılaştıkları sorunların tespiti amaçlanmıştır. 127 meslek mensubuna (serbest muhasebeci ve serbest muhasebeci mali müşavirler) anket formları ulaştırılmıştır. Araştırma sonucunda ise muhasebe meslek mensuplarının karşılaşmış oldukları sorunların çoğunlukla: iş yükünün çok fazla olması, alınan ücretlerin yetersiz olması, devlet dairelerinde bürokratik işlemlerin çokluğu, mükelleflerin evrakını zamanında ulaştırmaması, mükelleflerden muhasebe ücretlerinin zamanında veya hiç tahsil edilememesi şeklinde olduğu görülmüsstür. 
Tuğay ve Tekşen (2014) tarafından Burdur ilinde yapılan çalışmada bağımsız olarak çalışan muhasebe meslek mensuplarına anket uygulanmıştır. Çalışmanın sonucuna göre ise, muhasebe meslek mensuplarının sorunları olarak, muhasebeciden az vergi ödetmesinin istenmesi, mevzuat değişikliklerinin çok sık olması, haksız rekabetin olması, yoğun iş yükü, ücretlerin tahsilinde yaşanan problemler olarak tespit edilmiştir.

Deran ve Beller (2017) tarafından yapılan çalışma Niğde ilinde gerçekleştirilmiştir. Niğde ilinde faaliyet gösteren muhasebe meslek mensuplarının mesleki faaliyetlerini yerine getirirken karşılaştıkları mesleki sorunlar ile mükelleflerin karşılaştıkları sorunlar olarak, mevzuatın sık sık değişimi ile ilgili sorunlar, Tek Düzen Muhasebe Sistemi’nin uygulanması ile ilgili sorunlar, mükelleflerin muhasebe mesleğine yeteri kadar önem vermemeleri, mükelleflerin zamanında ve yeterli bilgi vermemeleri, mükelleflerden tahsil edilen ücretler ile ilgili sorunlar, mükelleflerin kanun dışı davranışlarda bulunma önerileri gibi sorunlar tespit edilmiştir.

Yapılan çalışmaların daha çok muhasebe meslek mensuplarının yaşadıkları sorunların tespitine yönelik olduğu görülmektedir. Bu araştırmada ise hem muhasebe meslek mensuplarının hem de vergi mükelleflerinin sorunlarının tespiti ve sorun karşısında ne tür çözüm önerilerinin olabildiği ayrıca bu durumların vergi uyumunu nasıl etkilediği nitel araştırma yöntemiyle tespit edilmeye çalışılmıştır. Dolayısıyla bu araştırmanın hem yöntemsel bağlamda hem de vergi uyumu özelinde literatüre katkı sağlayacağı beklenmektedir. Araştırmada ilgili tespitin yapılabilmesi için "Muhasebe meslek mensupları ile mükelleflerin karşılaştıkları sorunlar nelerdir? Mükellefler bir sorunla karşılaştı̆̆ında, muhasebe meslek mensuplarının bu sorun karşısındaki tutumu ve çözüm önerileri vergi uyumunu nasıl etkilemektedir?” sorusu dikkate alınmıştır. Araştırmada öncelikle kavramsal çerçeveye yer verilmiş ardından yönteme ilişkin açıklamalara yer verildikten sonra yapılan derinlemesine yarı yapılandırılmış görüşmelerden elde edilen bulgular alıntı yapılarak sunulmuş ve yorumlanmıştır. Araştırmanın son kısmında ise bulgulara yönelik olarak değerlendirmeler ve sonuç kısmı yer almaktadır.

\section{Yöntem}

$\mathrm{Bu}$ kısımda araştırmanın modeli, araştırmanın katılımcıları ve özellikleri, veri toplama teknikleri ve süreci, verilerin analizi ile araştırma etiği yer almaktadır.

\section{Araştırmanın Modeli}

$\mathrm{Bu}$ araştırmada, muhasebe meslek mensuplarının mesleki yaşantılarında karşılaştıkları sorunlar ile mükelleflerin iş yaşantılarında karşılaştıkları sorunların neler olduğu ve bu sorunlara ilişkin çözüm önerilerinin vergi uyumunu nasıl etkilediği tespiti amaçlandığından, araştırma nitel araştırma yöntemiyle gerçekleştirilmiş ve durum çalışması (case study) olarak desenlenmiştir. Nitel araştırma, gözlem, görüşme ve doküman analizi gibi nitel veri toplama tekniklerinin kullanıldığı, algıların ve olayların doğal ortamda gerçekçi ve bütüncül bir biçimde ortaya konulmasına yönelik nitel bir sürecin izlendiği araştırma olarak tanımlanabilir (Yıldırım ve Şimşek, 2013, s. 45). Nitel araştırmada yer alan desenler ise: "kültür analizi”, "olgubilim”, "kuram oluşturma”, "durum çalışması” ve "eylem araştırması”dır (Yıldırım ve Şimşek, 2013). 
Cresswell (2007) durum çalışmasını, araştırmacının sınırları belli bir sistemi, belli bir zaman dilimi içerisinde farklı kaynaklar kullanarak (gözlemler, görüşmeler, işitsel görsel materyaller, belgeler ve raporlar) detaylı bir şekilde betimlenmesi ve bu duruma dayalı temaların ortaya konulması olarak tanımlamıştır. Merriam (1998) ise nitel durum çalışmasını yoğun ve bütüncül bir betimleme olarak ve tek bir olayın, olgunun ya da toplumsal bir birimin analizi olarak tanımlamıştır.

Araştırmada izlenen aşamalar ilgili literatürün taranması ile başlayıp yarı yapılandırılmış görüşme formlarının hazırlanması, yarı yapılandırılmış görüşme formlarının uygulanması, verilerin analiz edilmesi, bulguların raporlaştırılması ve yorumlar ile sonuç kısmından oluşmaktadır. İzlenen bu aşamalar bir döngü şeklinde olup, geçerlik ve güvenirlik çalışmaları sürekli olarak yapılmıştır.

\section{Araştırmanın Katılımcıları ve Özellikleri}

Araştırmanın katılımcıları, amaçlı örnekleme yöntemlerinden biri olan "kartopu örneklem" ile seçilmiştir. Kartopu örnekleme, araştırmacının problemine ilişkin olarak zengin bilgi kaynağı olabilecek birey veya durumların saptanmasında özellikle etkilidir. Süreç çok basit bir soruyla başlar: "Bu konuda en çok bilgi sahibi kimler olabilir? Bu konuyla ilgili olarak kim veya kimlerle görüşmemi önerirsiniz?” (Patton, 1987, s. 56). Süreç ilerledikçe elde edilen isimler veya durumlar tıpkı bir kartopu gibi büyüyerek devam edecek, belirli bir süre sonra belirli isimler hep öne çıkmaya başlayacak, araştırmacının görüşmesi gereken birey sayısı veya ilgilenmesi gereken durum sayısı azalmaya başlayacaktır (Yıldırım ve Şimşek, 2013, s. 139).

Kartopu örnekleme yöntemiyle seçilen iki katılımcı grubunu muhasebe meslek mensupları ve vergi mükellefleri oluşturmaktadır. Görüşme yapılacak muhasebe meslek mensuplarının seçiminde alanında deneyimli olmasına, vergi mükelleflerinin seçiminde ise işinde uzun yıllar faaliyet göstermiş olmasına özen gösterilmiştir.

Araştırmanın katılımcı grubundan biri olan 25 muhasebe meslek mensubundan, 18'i serbest muhasebeci mali müşavirler iken 7'si ise yeminli mali müşavirlerden oluşmaktadır. Muhasebe meslek mensuplarının mesleki deneyimleri 3 ile 39 yıl arasında değişmektedir. 15 vergi mükellefinden oluşan bir diğer katılımcı grubu ise gelir vergisi mükellefleri ile kurumlar vergisi mükellefiyeti ile ilgisi bulunan mükelleflerden oluşmaktadır. Görüşme yapılan vergi mükelleflerinden $5{ }^{\prime} i^{5}$ büyük ölçekli işletme sahibi iken, kalan $10^{\prime} \mathrm{u}^{6}$ ise küçük ve orta ölçekli işletme sahibidir. Araştırmada veri çeşitliliğini artırmak için farklı sektörlerde (inşaat, otomasyon, bilişim, tarım, giyim sanayi vb.) faaliyet gösteren tecrübeli vergi mükellefleri ile görüşülmüştür. Mükelleflerin iş deneyimleri ise 2 ile 64 yıl arasında değişmektedir.

\section{Veri Toplama Teknikleri ve Süreci}

$\mathrm{Bu}$ araştırmada veriler "görüşme" tekniği kullanılarak toplanmıştır. Hem muhasebe meslek mensupları ile hem de mükellefler ile yapılan derinlemesine yarı yapılandırılmış görüşmeler yüz

\footnotetext{
${ }^{5}$ Mükellef (6), Mükellef (7), Mükellef (8), Mükellef (9), Mükellef (11).

${ }^{6}$ Mükellef (1), Mükellef (2), Mükellef (3), Mükellef (4), Mükellef (5), Mükellef (10), Mükellef (12), Mükellef (13), Mükellef (14), Mükellef (15),
} 
yüze, ses kayıt cihazı kullanılarak gerçekleştirilmiştir. Görüşme sorularının hazırlanması, uygulanması ve raporlaştırılması aşamalarının her birinde belirli aralıklarla, alan uzmanı, nitel araştırma uzmanı ve araştırmacının yer aldığı geçerlik komitelerinde, geçerlik ve güvenirlik çalışmaları yapılmıştır. Görüşmeler Eskişehir, Ankara ve İstanbul olmak üzere üç ilde gerçekleştirilmiştir. Veri toplama süreci ise 02.12.2017-05.08.2017 tarihleri arasını kapsamaktadır.

\section{Verilerin Analizi}

$\mathrm{Bu}$ araştırmada elde edilen veriler, nitel veri analizi yöntemlerinden tümevarım analizi yoluyla çözümlenmiştir. Tümevarım analizinde temel amaç, toplanan verileri açıklayabilecek kavramlara ve ilişkilere ulaşmaktır. Tümevarım analizinde birbirine benzeyen veriler belirli kavramlar ve temalar çerçevesinde bir araya getirilir ve bu veriler okuyucunun anlayabileceği bir şekilde düzenlenerek yorumlanmaktadır. Analiz süreci ise verilerin kodlanması, temaların bulunması, kodların ve temaların düzenlenmesi ile bulguların tanımlanması ve yorumlanması şeklindedir (Yıldırım ve Şimşek, 2013). Araştırma verilerinin analizi bilgisayar destekli nitel veri analizi programından biri olan NVivo 11 Pro yardımı ile gerçekleştirilmiştir.

\section{Araştırma Etiği}

Araştırmanın başlangıcından itibaren tüm verilerin geçerli bir şekilde toplanmasına özen gösterilmiştir. Gerçekleştirilen yarı yapılandırılmış görüşmeler ses kayıt cihazı ile kayıt altına alınmıştır. Yarı yapılandırılmış görüşmelerin öncesinde tüm katılımcılardan yazılı izin alınmıştır. Ayrıca araştırmaya dâhil olan katılımcıların isimleri kesinlikle deşifre edilmemiş, görüşme verilerinin analizinde katılımcı isimleri yerine SMMM (12), YMM (5) ve Mükellef (7) gibi kod isimler kullanılmıştır.

\section{Bulgular ve Yorumlar}

Araştırmanın bu kısmında 25’i muhasebe meslek mensubu 15 'i ise vergi mükellefi olmak üzere toplamda 40 katılımcidan toplanan verilerden elde edilen bulgular yer almaktadır. Bu bulgular araştırma sorusu olan, "Muhasebe meslek mensupları ile mükelleflerin karşılaştıkları sorunlar nelerdir? Mükellefler bir sorunla karşılaştığında, muhasebe meslek mensuplarının bu sorun karşısındaki tutumu ve çözüm önerileri vergi uyumunu nasıl etkilemektedir?” çerçevesinde hem muhasebe meslek mensuplarından hem de vergi mükelleflerinden elde edilen verilerden alınt ${ }^{7}$ yapilarak sunulmuş ve yorumlanmıştır.

\section{Muhasebe Meslek Mensuplarının Karşılaştıkları Sorunlar ve Çözüm Önerileri}

Muhasebe meslek mensupları ile yapılan görüşmeler neticesinde elde edilen veriler doğrultusunda öncelikle "Sorunlar" ana temasına ulaşılmıştır. Bu ana temadan iki ayrı temaya daha ulaşılmıştır. Bunlar ise: "Vergisel sorunlar" ile "Etik ve ahlakî sorunlar" şeklindedir. "Vergisel sorunlar" alt temasından ise "Çözüm önerileri", "Cezalar ve cezaların fonksiyonu" ve "Edinilen tecrübeler" olmak üzere üç alt temaya daha ulaşılmıştır. İlgili temaların frekans dağılımı ${ }^{8}$ aşağıdaki şekil yardımıyla açıklanmıştır.

\footnotetext{
${ }^{7}$ Alıntı yapılarak sunulan görüşme verilerinin sonunda yer alan tarihler, görüşmenin yapıldığı tarihi belirtmektedir.

${ }^{8}$ Frekans dağılımı, muhasebe meslek mensuplarının görüşlerinin sayısını ifade etmektedir.
} 


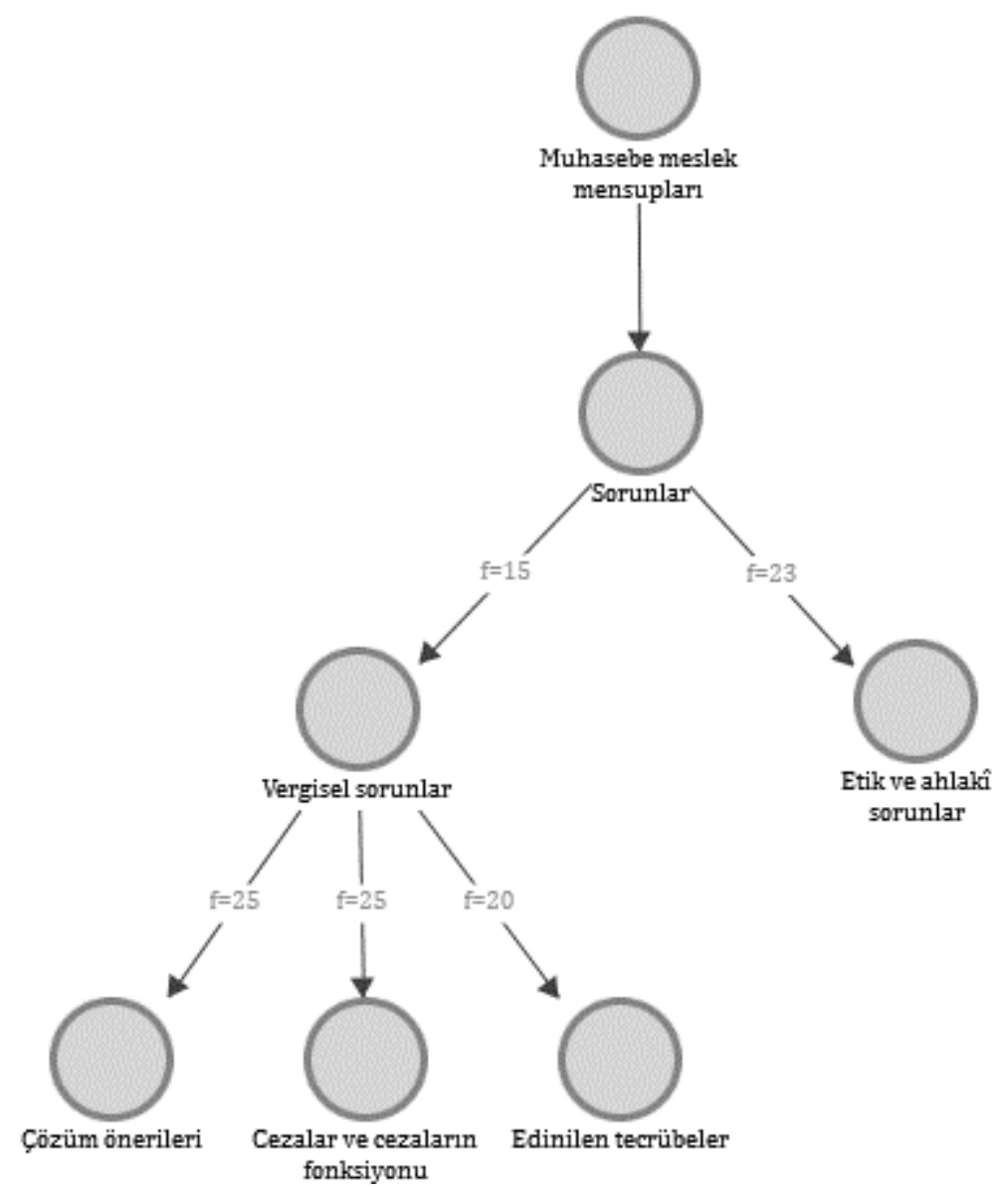

Şekil 1. Muhasebe Meslek Mensupları Açısından "Sorunlar" Adlı Ana Tema ve Alt Temalar

\section{Vergisel Sorunlar}

Muhasebe meslek mensuplarından $15^{\prime} \mathrm{i}^{9}$ vergisel sorunların neler olduğu ve hangi durumların bu sorunlara sebebiyet verdiği konusunda görüş bildirmiştir. SMMM (16), vergisel sorunların nedenini mevzuatın açık olmamasına bağlamış ve şu şekilde ifade etmiştir:

SMMM (16): (...) Mevzuat çok karışı. Sade değil. Özellikle gelir vergisiyle KDV’nin birbirleriyle uyumsuzluğu. İşte bir kanun kabul ederken birisi etmeme, KDV’sini gider yazmama, özellikle son dönemde sikıntılarımız var. (...) (06.06.2017)

SMMM (9)'un ise “...Mevzuat açık değil bir de sürekli mevzuat değişikliği var ama sürekli yani...” şeklindeki görüşü, SMMM (16)'nın yukarıdaki görüşünü destekler nitelikte bir bulgudur.

SMMM (6), mükellefin bilgisizliğinden ve bakış açısından kaynaklanan durumların vergisel sorun oluşturduğunu şu şekilde açıklamıştır:

SMMM (6): Güncel olarak karşılaştığımız sorun Katma Değer Vergisi. KDV'yi kendi cebinde kalan bir para olaraktan düşünüyor. Mükellef verdiği zaman bunu cebinden çımış bir şey olaraktan düşünüyor,

9 SMMM (2), YMM (3), SMMM (5), SMMM (6), SMMM (9), SMMM (16), SMMM (17), SMMM (11), SMMM (12), SMMM (13), SMMM (14), SMMM (15), YMM (20), YMM (22), YMM (23). 
ama şeyde tabii mevzuatta bu emanet bir para. O emanet parayı cebinde tutmanın derdine düşmüş mükellefler olabiliyor. Onun dışında da kanunen kabul edilmeyen giderlere atılan, kendi şahsi ve ailesine ait harcamalar oluyor mesela mükelleflerin. Onların hepsini şirkete fatura kesebiliyorlar. Kurumlar Vergisinden geçici vergiden düşürmek için. Onlar sıkıntı oluyor. (...) (08.05.2017)

YMM (22) ise, YMM (6)'nın yukarıdaki görüşüne benzer bir görüş bildirerek vergisel sorunların mükelleften kaynaklandığını, ayrıca mükellefin işine geldiği gibi işlemleri yaptığını ve işlemleri vergi mevzuatına uygun haline getirme kısmını ise muhasebe meslek mensubuna bıraktığını şu şekilde ifade etmiştir:

YMM (22): (...) Vergi sorununun esası mükelleften kaynaklanır. Çünkü o birçok şeyi aslında muhasebeye gelmeden önce bitirmiştir. Açıktan mal alıp satacaksa onu yapmıştır. Kayıt kısmını meslek mensubu arkadaşımıza verir. (...) (20.06.2017)

Elde edilen bulgular;

- Vergi sorunlarının nedeninin mevzuattaki sık sık değişimlerden kaynaklandığını,

- Vergi mevzuatının açık olmadığını ve

- Temel sorunun mükelleflerin vergi konusunda bilgi sahibi olmamasından kaynaklandığını, diğer taraftan ise mükelleflerin kendi işlerine nasıl geliyorsa öyle bir davranış biçimi de geliştirebildiklerini göstermektedir.

Sonuç olarak muhasebe meslek mensupları her ne kadar vergi sorunlarının sebebini mevzuatın açık olmaması ve mevzuatın sık sık değişiyor olmasına bağlasa da temel sıkıntının daha çok mükelleften kaynaklandığını belirtmiştir. Mükellef tarafından kaynaklanan sorunların temelinin vergi konusundaki bilgisizliğe dayandığı ve ayrıca mükelleflerin işlerini yasal prosedürleri önemsemeyip kendi bildikleri gibi yaptıkları da ifade edilmiştir.

\section{Çözüm Önerileri}

Görüşme yapılan muhasebe meslek mensuplarının hepsi mükelleflerin vergisel sorunla karşılaştığında ya da vergi cezası aldığında neler önerdiklerine ilişkin görüş bildirmiştir.

SMMM (1), mükelleflerinin vergi sorunuyla karşılaşmaması için önceden olabildiğince önlem aldığını ve mükelleflerini uyardığını eğer bir cezaya maruz kalındıysa sorunun tespitinin önemini ve çözüm önerisini ise şu şekilde açıklamıştır:

$\operatorname{SMMM(1):~(...)~Vergi~cezası~almaması~için~neler~yapması~gerektiğini~anlatıyorum~demiştim.~Bir~mükellef~}$ neden vergi incelemesine girer, onları kendilerine izah ediyoruz. Vergi incelemesine girip cezai işleme maruz kaldıysa tabii burada öncelikle kendimize soruyoruz çünkü acaba muhasebe iş ve işlemlerinde bir hata yaptık da bundan dolayı mı ceza kesildi, yoksa biz mükellefe izah ettiğimiz halde mükellef ödevini yerine getirmedi bundan dolayı mı ceza kesildi. Bunun ayrımını yapmamız çok önemli. Bizden kaynakliysa zaten ben kendimi o konuda yetersiz kalma konusunda bilgi takviyesi yapıyorum. Ama mükellefte bir sıkıntı varsa tekrar kendisine o doğrultuda neler yapılması gerektiğini hem işletmede birebir çalışan personele hem de mükellefe anlatıyoruz böyle böyle diye bire bir izah ediyoruz. (...) (02.12.2016) SMMM (11) ise cezalandırma işlemini, eylem ortaya çıktıktan sonra çözüm önerilerini şu şekilde açıklamıştır: 
SMMM (11): (...) Yapılabilecek neler varsa onları yapmaya çalışıyorsunuz. İşte vergi incelemesinde uzlaşma yoluna gitmemiz gerekiyorsa uzlaşma yoluna gidiyoruz. Uzlaşma talep ediyoruz. Tarhiyat öncesi tarhiyat sonrası uzlaşma. Emsal karar varsa dava açılması gerekiyorsa dava açtıklarımız var. Dava yoluna gidebiliyoruz. Veya işte taksitlendirilmesi gerekiyorsa ödenmesi gerekiyorsa o tür bir işlem yapıyoruz. (...) (12.05.2017)

SMMM (12) ise mükelleften ya da kendisinden kaynaklı herhangi vergisel bir sorunla karşılaştığında hangi durumda daha fazla fayda sağlayacağını çevresinden fikir alarak değerlendirdiğini ve ona göre bir çözüm önerisi sunduğunu ayrıca mükelleflerine verdiği tavsiyeleri şu şekilde izah etmiştir:

SMMM (12): (...) Araştırma yapıyoruz işte gruplardan paylaşımlarla nassl bir çözüme ulaşabiliriz. Başlarına gelen arkadaşlarımız var mı, bunu nasıl bir yolla şey yapılmış ona göre hareket ediyoruz. Mükellef ne derecede hasar az görürse ona göre değerlendiriyoruz. (...)

\section{(...) Bizden kaynaklanıyorsa onu da aynı şekilde araştırıyoruz ve biz ödüyoruz. (...)}

(...) Mükelleflere o cezaları bir daha yapmamalarını naylon faturalarla veya değişik şeylerle uğraşmamalarını tavsiye ediyoruz. Yani mesela kâr çok çlkıyor vatandaş diyor ki fatura bulalım. Buluyorlar gidiyorlar o faturayı yüzde 3 yüzde $5 \mathrm{KDV}$ ödüyorlar. Sonra Maliye yakaladı̆̆ zaman yüzde 18 alıyor üzerine bir ceza alıor. (...) (30.05.2017)

SMMM (12)'nin yukarıdaki söyleminden aslında mükelleflerin muhasebe meslek mensubunun tavsiyelerini ciddiye almadıklarını dolayısıyla meslek mensubunun burada bir fonksiyonunun olmadığını ve mükellefin kendi bildiğini yaptığı anlaşılmaktadır.

SMMM (14) ise, herhangi bir cezaya maruz kalma ihtimaline karşı mesleki sorumluluk sigortası yaptırdığını şu şekilde izah etmiştir:

SMMM (14): (...) Hatadan kaynaklı birtakım sorunlar oluşabilir. Yani işte orada 100 yazıyordur da siz sıfira bir tane eksik basmışsınızdır 10 yazmışsınızdır. Bu mukabil vergi sorunları yaşayabiliriz. Devlet diyor ki arkadaşım yani zaten bu olaylar kaçakçllık suçlarını bağlamıyor. Hatadan oluşan birtakım yanlışlar söz konusuysa bunları ortadan kaldırmanızı sağlayacak bir durum. Yani böyle bir sigorta poliçesi satın almak istiyorsanız sizin bileceğiniz iş. Yani mesleki sorumluluk sigortası yaptırıyorum. (...) (05.08.2017)

Elde edilen bulgular;

- Vergisel sorun çıkmaması için mükellefin daha önce uyarıldığını,

- Diğer taraftan muhasebe meslek mensubunun uyarılarını dikkate almayan mükelleflerin de olduğunu,

- Eğer mükellef cezaya maruz kaldıysa durumun elverdiği ölçüde yasal çözüm yollarına başvurulduğunu, 
- Vergisel sorunun kaynağının belirlenmesi noktasında, eğer sorun muhasebe meslek mensubundan kaynaklanıyorsa meslek mensubunun bu sorumluluğu üstlenerek cezayı ödeyebildiğini,

- Diğer taraftan süreç içerisinde muhasebe meslek mensuplarının aslında sorun olabilecek durumları görebildiğini, böyle bir durumda ise ya bu sürecin parçası olduğunu ya da sessiz kaldığını göstermektedir.

Sonuç olarak muhasebe meslek mensuplarının vergisel sorun çıkmadan önce mükellefi uyardıklarını, mükellef eğer ceza almış ise durumun izin verdiği ölçüde optimal fayda sağlayacak çözüm yollarına başvurduklarını göstermektedir. Bu çözüm yolları ise; dava açmak, uzlaşmaya başvurmak, pişmanlıkla dilekçe vermek, vergi affından yararlandırmak, cezalarda indirimden faydalanmak vb. şeklinde sıralanabilir. Eğer vergisel sorun muhasebe meslek mensubunun kendisinden kaynaklanıyor ise bu cezayı üstlenip ödeyebildikleri ifade edilmiştir. Muhasebe meslek mensuplarından sadece $1^{\prime} \mathrm{i}^{10}$ ise yüksek tutarlı bir cezaya maruz kalma ihtimaline karşın mesleki sorumluluk sigortası yaptırdığını ifade etmiştir.

\section{Cezalar ve Cezaların Fonksiyonu}

Görüşme yapılan muhasebe meslek mensuplarının hepsi cezalar ya da cezaların fonksiyonu konularında görüş bildirmiştir. Muhasebe meslek mensuplarından 12 ' $\mathrm{si}^{11}$ vergi uyumunun artırılmasında vergi cezalarının etkili olmadığını belirtirken, $11^{\prime} \mathrm{i}^{12}$ ise vergi uyumunun artırılmasında vergi cezalarının kısmen etkili olduğunu belirtmiştir. $8^{13}$ muhasebe meslek mensubu ise özellikle bazı cezaların miktar itibariyle çok fazla olduğunu ifade etmiştir.

SMMM (15), mevcut yasada yer alan birtakım uygulamalardan dolayı cezaların işlevinin olmadığını şu şekilde açıklamıştır:

SMMM (15): (...) Cezaların hiçbir fonksiyonu yok. Yok, çünkü neden, vergi cezalarında şu var vergi cezaları uygulanıyor ama uzlaşma komisyonları artı 376'ncı madde cezada indirim maddeleri uygulanıyor. Bunları uyguladığı zaman zaten cezanın bir anlamı kalmıyor. (...) (31.05.2017)

SMMM (16) ise vergi uyumunun artırılmasında cezaların fonksiyonunun mükellef grubuna göre değişebileceğini şu şekilde ifade etmiştir:

SMMM (16): (...) Kişiye bağlı kimisi zaten dersini alacağı dersi alabiliyor. Kimisi de zaten işin sonucuna kadar bizden iyi biliyor. (...)

(...) Yani onu düzgün yapmakla ne kadar maliyete katlanacak, incelenip ceza kesildiğinde ne kadar ceza kesilecek, hangisinin kârlı olup olmadığını uzlaşmaya girince sonucunun ne olacağını yani o yola girmiş insan zaten onları düşünüyor. (...) (06.06.2017)

\footnotetext{
${ }^{10}$ SMMM (14)

${ }^{11}$ SMMM (1), YMM (4), SMMM (5), SMMM (7), SMMM (8), SMMM (10), SMMM (11), SMMM (13), SMMM (14), SMMM (15), YMM (20), YMM (23).

${ }^{12}$ YMM (3), SMMM (6), SMMM (9), SMMM (16), SMMM (17), SMMM (18), SMMM (19), YMM (21), YMM (22), SMMM (24), YMM (25).

${ }^{13}$ SMMM (2), SMMM (5), SMMM (8), SMMM (9), SMMM (12), SMMM (17), SMMM (18), YMM (22).
} 
Diğer taraftan SMMM (11)'in vergi uyumunun artırılmasında cezalardan ziyade öncelikle vergi mükelleflerinin bilinçlendirilmesi gerektiğini örneklendirerek ifade ettiği “...İnsanları düzeltmek için cezayı kullanmak çok doğru bir yöntem değil. Yani önemli olan cezayla düzeltmek değil. Yani o şeyin yanlışlığını veya yapması gerektiğini o kişiye anlatmanız lazım. Yani şimdi örnek veriyorum siz işte emniyet kemeri takmanın şeyini yolunu ceza kesmekte görürseniz yani polis görünce takar. Ama işte o insana emniyet kemerinin aslında takıldığında kendisine nasıl bir fayda, çevresine nasıl bir fayda sağlayacă̆ını anlatabilirseniz o zaman faydalı olur..." şeklindeki görüşü ile SMMM (13)'ün “...Illk önce insanları bilinçlendirmek gerekiyor. Yani bilinçlendirme de ta küçükten başlıyor öyle sonradan olan bir şey değil aslında. Yani bir ticaretin ne olduğunu küçük yaşta anlatmak gerekiyor..." şeklindeki görüşü birbirini destekler nitelikteki bulgulardır. Elde edilen bulgular;

- Muhasebe meslek mensuplarının bir kısmı vergi uyumunun sağlanmasında cezaların etkili olmadığını, bir kısmı da cezaların kısmen etkili olduğunu ifade etmiştir.

- Mevcut sistemde yer alan uzlaşma, cezalarda indirim gibi uygulamaların cezaların işlerliğini yitirmesine neden olduğunu,

- Mükellefin cezaya olan algısının da önem teşkil ettiğini çünkü ceza bir kısım mükellef grubu için caydırıcı olabilecekken bir kısım mükellef için de cezanın bir anlam ifade etmediğini ve

- Vergi uyumunun sağlanması için cezadan ziyade öncelikle mükelleflerin bilinçlendirilmesi için eğitim programlarının gerekli olduğunu göstermektedir.

Sonuç olarak vergi uyumunun artırılmasında vergi cezalarının etkili olmadığı ya da kısmen etkili olduğu tespit edilmiştir. Vergi uyumunun sağlanmasında cezaların bir noktaya kadar etkili olduğu, buna karşın öncelikli olarak toplumda vergi bilincinin artırılmasına yönelik tedbirlerin alınmasının sorunların çözümünde daha etkin olabileceği tespit edilmiştir.

\section{Edinilen Tecrübeler}

Görüşme yapılan muhasebe meslek mensuplarından $20^{\prime} \mathrm{si}^{14}$ daha önce yaşadıkları tecrübelerin sonraki vergi sorunlarına ne şekilde yansıdığı konusunda görüş bildirmiştir.

SMMM (11), bu konudaki görüşünü sürekli yasa dışı girişimlerde bulunan mükelleflerin cezaya maruz kalmalarının kendilerinin mükellefleri ikaz etmelerinden daha etkili olduğunu şu şekilde açıklamıştır:

SMMM (11): (...) Mükellef bazı şeyleri ceza yemeden uygulamıyor maalesef ki. İlla yani bir şekilde bir şeylerden ağzı yanacak ki ancak o zaman izah edebiliyoruz. Yani anlatamıyoruz mesela işte piyasadaki naylon fatura kullanımını izah edemiyoruz. (...)

(...) Tabii o ceza deneyimini bir yaşaması gerekiyor çoğunun. Yani dolayısıyla tabii onu yaşadıktan sonra da sonraki bakış açısı değişiyor. (...) (12.05.2017)

\footnotetext{
${ }^{14}$ SMMM (2), YMM (3), YMM (4), SMMM (5), SMMM (6), SMMM (9), SMMM (11), SMMM (12), SMMM (13), SMMM (14), SMMM (15), SMMM (16), SMMM (17), SMMM (18), SMMM (19), YMM (20), YMM (21), YMM (22), YMM (23), SMMM (24).
} 
SMMM (5)'in “...Mükelleflerin illa ki bir başına gelecek, vergi incelemesi veya benzeri bir şeyle karşılaşacaklar. Bir ders alacaklar. Ondan sonra bizim sözümüze tekrar gelecekler...” şeklindeki söylemi ile YMM (22)'nin “...Vergi ödevini yerine getirmeyen insan bir travma yaşar. Travmadan her zaman ders çıkarılır... Vergi cezası yiyen mükellefler bir daha tedirgin olur ve bundan ders alırlar çıkarırlar...” şeklindeki söylemi, SMMM (11)'in yukarıdaki görüşünü destekler nitelikteki bulgulardır.

SMMM (14), vergi idaresinin dürüst mükelleflere bakış açısının farklı olduğunu, olumsuz bir durum yaşandığında bunun hata olabileceği varsayımından hareket ettiklerini dolayısıyla olumlu tecrübelerin verginin tarafları arasındaki ilişkilere de yansıdığını şu şekilde izah etmiştir: SMMM (14): (...) Bir konu hakkındaki hızlı çözümünüz, aktif tutumunuz, doğru yaklaşımınız mutlaka idare nezdinde evet bu mükellef düzgün mükelleftir, hani bir şey varsa bile bu bir hatadır ve bunu aktardığımızda mutlaka yasal anlamda giderilecektir fikri var. Oluşturmaya çalıştı̆̆ımızda budur yani biz ne kadar doğru düzgün, düzenli güvenilir dürüst bir çalışma yaparsak bizim ilişkide olduğumuz devlet kurumlarıdır, Odalardır, Ticaret Odasıdır, ne bileyim Ticaret Borsasıdır kim varsa ilişkide olduğumuz insanlar, bu etkileşimden mutlaka etkileniyorlar. Yani bu davranış tutumlar onlan da ekiliyor. Illişkiler de bu anlamda daha samimi sıcak dürüst gerçekleşiyor. (...) (31.05.2017)

SMMM (15) ise devlet tarafından getirilen matrah artırımı gibi bir takım uygulamaların, yaptırımların caydırıcılığını azalttığını ve bu durumun vergi uyumsuzluğunu artırdığını şu şekilde açıklamıştır:

SMMM (15): (...) Her 5 yılda bir ülkemizde matrah artırmak suretiyle bütün suçlu insanlar yani hapisten kurtulur dışarıya çıkarlar. Öyle diyelim yani olaya öyle bakmak lazım. Tabii insanlara sürekli bunu yaptığımız takdirde biz de müşteriyle iletişime geçerken işte bunu soruyor, nasılsa 5 yıl sonra vergi matrahı artırımı olur o zaman diyor. (...)

(...) Vergi ödememek için veya vergiden kaçınma, vergi kaçırma gibi bütün isteklerini daha da artırıor şu anda. (...) (31.05.2017)

Elde edilen bulgular;

- Muhasebe meslek mensuplarının uyarılarının çoğu kez dikkate alınmadığını,

- Mükelleflerin özellikle cezaya maruz kaldığında bu durumun sonraki sorunların oluşumunu engelleyebildiğini ve vergi karşısındaki tutumlarının değişebildiğini,

- Deneyimlenen olumsuz tecrübelerden, alınan cezalardan ders çıkarılabildiği, bunun vergi uyumunu artırmada olumlu bir etki oluşturabildiğini,

- Vergisini düzenli olarak ödeyen mükellef için ise vergi dairesinin o mükellef için olumlu bir bakış açısı geliştirebildiği, aynı mükellefin yasaya aykırı eylemlerinde idare mükellef hakkında olumlu görüşe sahip olduğundan, idarenin bu eylemleri kabul edilebilir bir hata olarak değerlendirebileceğini ve

- Vergi sisteminde yer alan matrah artırımı gibi uygulamaların mükellefin bakış açısını değiştirebildiğini, yaptırımların caydırıcılığını azalttığını ve bu durumun vergi uyumunu azaltabildiğini göstermektedir. 
Sonuç olarak muhasebe meslek mensuplarının mükellefleri vergi ödevlerinin olması gerektiği gibi yapılması noktasında yönlendirdikleri ve uyarıda bulundukları ancak bu uyarıların mükellefler üzerinde etkili olmadığı tespit edilmiştir. Mükelleflerin ancak cezaya maruz kaldığında durumun ciddiyetini anladıkları ve bu durumdan ders çıkarabildikleri görülmektedir. Diğer taraftan deneyimlenen olumsuz tecrübelerin bir sonraki vergi uyumsuzluğunu engelleyebileceği gibi, iyi tecrübelerin ise verginin tarafları arasındaki ilişkileri olumlu etkileyebildiği ortaya çıkmıştır. Ayrıca vergi sistemindeki matrah artırımı gibi uygulamaların cezaların caydırıcılığını azalttığını, dolayısıyla vergi uyumu üzerinde olumsuz etki oluşturduğu tespit edilmiştir.

\section{Etik ve Ahlakî Sorunlar}

Görüşme yapılan muhasebe meslek mensuplarının 23 '̈̈ ${ }^{15}$ mesleklerini icra ederken yaşamış oldukları etik ve ahlakî sorunlardan bahsetmiştir. Her ne kadar meslek etiğinin gereklerine uygun davrandıkları yönünde görüş bildiren muhasebe meslek mensupları olsa da söylenen bu durumun gerçeği yansıtmadığı aşağıdaki dikkat çekici verilerden anlaşılmaktadır.

SMMM (6), meslek etiğinin gerekleri ile mükellef talepleri arasında bir uyuşmazlık çıktığında tercihini mükellefin talebi yönünde kullandığını şu şekilde açıklamıştır:

SMMM (6): (...) Genel anlamda yüzde 90 mükellefin beklentisi doğrultusunda oluyor ama çok da doğru bir şey değil tabii ki. Ama piyasa maalesef ki bunu götürüyor. Çünkü dışarıda 150, 200 liraya hesap tutan firmalar var. Mali müşavirler var. Onlarla rekabet etmeniz gerekiyor. Orada etik metik kalmıyor yani zaten etik başta gitmiş 150, 200 liraya defter tutan mali müşavir veya kiralık ruhsat kullanan kişiye ben mesleki etik açısından davranırsam olmaz. (...) (08.05.2017)

SMMM (8)'in “...Açık konuşmak gerekirse piyasa belirliyor. Dolayısıyla müşterinin dediği oluyor, mümkün mertebe. Çünkü serbest meslek adı üzerinde, dolayısıyla bu şartlara uymanız gerekiyor...” şeklindeki görüşü, SMMM (6)'nın yukarıdaki görüşünü destekler nitelikte bir bulgudur. Dolayısıyla bu söylemlerden muhasebe meslek mensuplarının piyasada var olabilmek ve yeterince kazanç elde edebilmek için mükelleflerin taleplerini göz ardı edemediklerini dolayısıyla bu noktada etik ve ahlakî sorunların oluşumuna da sebebiyet verdikleri sonucu çıkartılabilir.

YMM (22) ise mesleklerinde haksız rekabetin özellikle serbest muhasebeci mali müşavirler arasında fazla olduğunu belirtmiş ve bu durumu ise sayılarının fazla olmasına bağlamıştır. Ayrıca büyük denetim şirketlerinin de bu duruma ortak olduğunu belirten katılımcı, haksız rekabetin olduğu yerde meslek etiğinin olmayacağını şu şekilde açıklamıştır:

YMM (22): (...) Serbest mali müşavirlerin sayılarının fazla olması nedeniyle bunlar ücret yönüyle haksız rekabet yapıyorlar. Hat safhada yapıyorlar. Haksız rekabetin olduğu yerde etik olmaz. Toplumsal bir yaradır. Mesleği yok eder. Mesleğin saygınlığını duyarlılığını mükellefle yani müşterilerle olan ilişkilerini

\footnotetext{
${ }^{15}$ SMMM (1), YMM (3), SMMM (5), SMMM (6), SMMM (7), SMMM (8), SMMM (9), SMMM (10), SMMM (11), SMMM (12), SMMM (13), SMMM (14), SMMM (15), SMMM (16), SMMM (17), SMMM (18), SMMM (19), YMM (20), YMM (21), YMM (22), YMM (23), SMMM (24), YMM (25).
} 
zedeler. Maalesef bu noktadayız. Yeminli mali müşavirler açısından 4 büyükler 5 büyükler dediğimiz firmalar vardır. Bunlar yabancı partnerlerle çalışırlar. İsimleri bellidir. Ve bunlar asgari ücret tarifemizin çok altında yarısına 3'te 1'ine iş alıp arkadaşlarının ekmeklerini elinden almaktadırlar. (...) (20.06.2017) Elde edilen bulgular;

- Meslek etiğinin gerekleri ile mükellef talepleri arasında bir uyuşmazlık çıktığında tercihini mükellefin talebinden yana kullandığını ifade eden muhasebe meslek mensuplarının olduğunu,

- Bu durumun ise etik ve ahlakî sorunlara sebebiyet verdiğini,

- Haksız rekabet ortamının oluştuğunu belirten muhasebe meslek mensuplarının sayıca fazla olduğunu göstermektedir.

Sonuç olarak meslek etiği kurallarının ihlal edildiği ve özellikle asgari ücret tarifesinin altında hizmet veren muhasebe meslek mensuplarının olduğu tespit edilmiştir. Diğer taraftan ücretini mükelleften alan muhasebe meslek mensubunun piyasa şartlarına uyum sağlayarak mükellefin talebini gerçekleştirme noktasında kendilerini zorunlu hissettiklerini belirten muhasebe meslek mensuplarının olduğu görülmektedir.

\section{Vergi Mükelleflerinin Karşılaştıkları Sorunlar ve Çözüm Önerileri}

Vergi mükellefleri ile yapılan görüşmeler neticesinde elde edilen veriler doğrultusunda yine "Sorunlar" adlı ana temaya ulaşılmıştır. Bu ana temadan ise "Muhasebe meslek mensuplarının fonksiyonu", "Başvurulan yollar" ve "Vergi cezaları" olmak üzere üç alt temaya daha ulaşılmıştır. İlgili temaların frekans dağılımı ${ }^{16}$ aşağıdaki şekil yardımıyla açıklanmıştır.

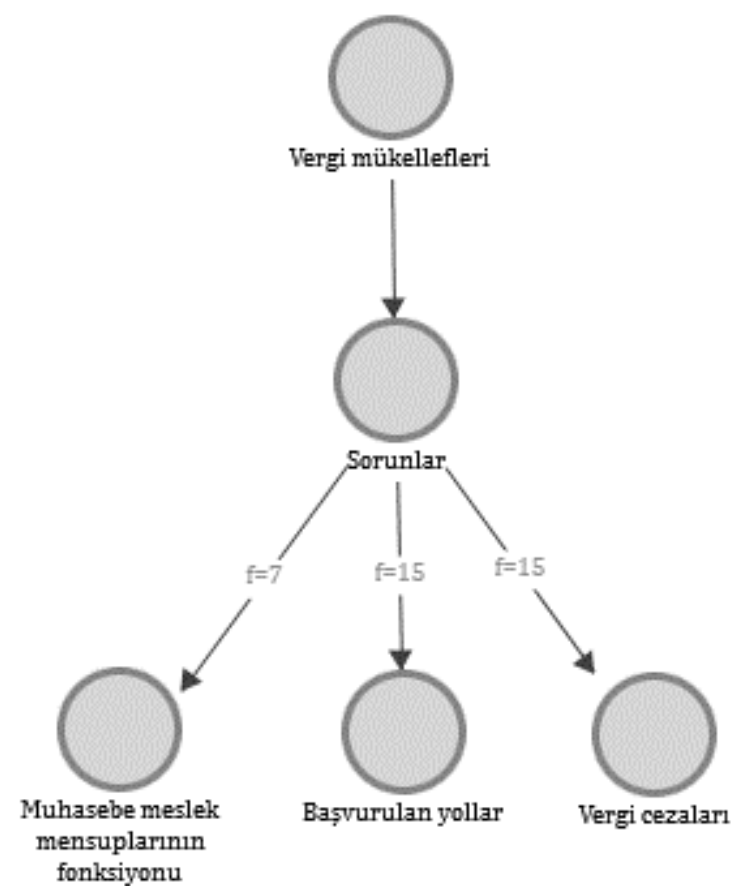

Şekil 2. Vergi Mükellefleri Açısından “Sorunlar” Adlı Ana Tema ve Alt Temalar

\footnotetext{
${ }^{16}$ Frekans dağılımı, vergi mükelleflerinin görüşlerinin sayısını ifade etmektedir.
} 


\section{Muhasebe Meslek Mensuplarının Fonksiyonu}

Görüşme yapılan vergi mükelleflerinin $7^{\prime} \mathrm{si}^{17}$ vergisel sorun karşısında muhasebe meslek mensuplarının fonksiyonunun nasıl olduğu ya da olabileceği konusunda görüş bildirmiştir.

Mükellef (1) eğer bir vergisel sorunla karşılaşsaydı muhasebe meslek mensubunun ona destek olacağını düşündüğünü “...Hiç karşılaşmadım ama bana destek olacağını, yardımcı olacağını kesinlikle zannediyorum...” şeklinde ifade etmiştir.

Dava konusu bir işlemin varlığı halinde ise Mükellef (8)'in “...Mali müşavir elinden geldiği kadar destek oluyor. Tabii bu desteğin dışında da hukuki yönlerine de avukat lazım...” şeklinde ifade ettiği görüşü ile Mükellef (2)'nin ise “...Konuyla ilgili bir avukat olması lazım. Çünkü özel branşlar...” şeklinde ifade ettiği görüşü birbirine benzer nitelikte bulgulardır.

Diğer taraftan vergisel sorunla başa çıkma konusunda muhasebe meslek mensuplarına ihtiyaç duyduğunu ifade eden Mükellef (4), bu sorunun kendisinden kaynaklandığını, vergi ödememek için sahte faturayı meslek mensubuna işlettirdiğini şu şekilde açıklamıştır:

Mükellef (4): (...) Burada onların desteği olmadan zaten ben dâhil hiçbir mükellef doğru ilerleyemez. (...)

(...) Belki ben biliyorum onun naylon olduğunu, alıyorum işlettiriyorum yok yok naylon değil diye. Bunu biliyorsunuz kâğıt altı üstü. E-fatura sistemiyle düzenliyoruz biraz da. Zaten bundan kaçmak maksat. (...)

(...) Aslında onlar olmadan biz vergi dairesiyle hiçbir şekilde başa çıkamayız. (...) (19.06.2017) Elde edilen bulgular;

- Vergisel bir sorun karşısında muhasebe meslek mensuplarının kendilerine destek olduğunu ve kendilerini yönlendirdiklerini ifade eden vergi mükelleflerinin olduğunu,

- Mükellefler eğer dava konusu bir işlem varsa bu noktada özel branş gerektirdiği için avukata ihtiyaç duyulabildiğini ve

- Ticari hayatta olağan kabul edilebilen ancak vergi mevzuatına aykırılık teşkil eden ve cezalandırma gibi sorun çıkabilecek durumlarda, mükellefleri muhasebe meslek mensuplarının kurtardığını göstermektedir.

Sonuç olarak vergisel bir sorun karşısında muhasebe meslek mensuplarının fonksiyonunun önemli olduğu tespit edilmiştir. Muhasebe meslek mensupları mükellefleri yönlendirerek ve onlara destek olarak vergisel sorun yaşamalarına engel olabilmektedir. Diğer taraftan bir vergi mükellefinin de ifade ettiği gibi yasa dışı bir eylemde bulunduğunda da vergi mükellefinin muhasebe meslek mensubunu kendisine destekçi olarak gördüğü tespit edilmiştir.

\section{Başvurulan Yollar}

Kendileriyle görüşme yapılan vergi mükelleflerinin hepsi vergisel bir sorun karşısında hangi yollara başvurduklarına ilişkin görüş bildirmiştir.

\footnotetext{
${ }^{17}$ Mükellef (1), Mükellef (2), Mükellef (4), Mükellef (6), Mükellef (7), Mükellef (8), Mükellef (9).
} 
Mükellef (15), matrah artırımında önceden bir defa bulunduklarını ancak şu anda para kazanamadığı için matrah artırımında bulunamadıklarını şu şekilde açıklamıştır:

Mükellef (15): (...) Herhalde bir sefer bulunduk galiba. Zaten bizim rakamlar yüksek. Şimdi eskiden matrah artırımı yapıyorduk. Şimdi stokçuluk bitti. Niye artıracaksın ki mobilya sektörü 2000 yılından bu yana, eskiden para kazandık. Şimdi yüzde 10’u yakalasak oynarım. Sıkıntı burada. Matrahı nasıl artıracaksin. (...) (05.08.2017)

Diğer taraftan Mükellef (2) ise, pişmanlıkla beyanname verdiklerini bunun nedeninin ise $\mathrm{Ba} / \mathrm{Bs}$ formlarında yanlışlıkla yapılan bir hatadan kaynaklandığını şu şekilde açıklamıştır:

Müikellef (2): (...) Pişmanlıkla beyanname verdik. Nasıl verdik, sehven yapılan bir hata vardı onlarla ilgili bir beyanname verildi ama çok basit bir olaydı. BA/BS ile ilgili bir beyandı. (...) (01.06.2017)

Elde edilen bulgular;

- Mükelleflerin vergisel sorunla karşı karşıya kaldıklarında vergi sisteminde yer alan yasal yollara başvurduklarını göstermektedir.

Sonuç olarak vergi mükelleflerinin pişmanlıkla beyanname verdikleri, cezalarda indirimden ve vergi aflarından yararlandıkları, uzlaşma talebinde ve matrah artırımında bulundukları tespit edilmiştir. Mükelleflerin yasal imkânların teknik detaylarından çok haberdar olmamakla birlikte muhasebe meslek mensupları vasıtasıyla bu tür başvuru yollarından yararlanılabildiği görülmektedir. Diğer taraftan mükelleflerin görüşlerini ifade ederken galiba, herhalde, tam detaylı bilmiyorum gibi kelimeleri sıklıkla kullandıkları görülmektedir. Bu durumun nedeni ise mükelleflerin muhasebe meslek mensuplarınca bilgilendirildiği, ilgili konulara mükelleflerin hâkim olmadıkları olabilir.

\section{Vergi Cezaları}

Görüşme yapılan vergi mükelleflerinin hepsi vergi cezası alıp almadıkları ya da cezai yaptırımların caydırıcılığı hakkında görüş bildirmiştir. Mükelleflerin hepsi büyük meblağ içeren vergi cezalarına maruz kalmadıklarını belirtmişlerdir. Cezaların caydırıcılığı konusunda mükellefler arasında görüş ayrılıkları bulunmaktadır. Mükelleflerden 7 'si ${ }^{18}$ vergi cezalarının caydırıcılık yönünün olduğunu ifade ederken, 2 ' si $^{19}$ caydırıcılık yönünün olmadığını ifade etmiş, $3^{\prime} \ddot{u ̈}^{20}$ ise caydırıcılık yönünün kişiye göre değişebileceğini ifade etmiştir.

Vergi cezası almadığı aynı zamanda cezaların caydırıcı yönünün olduğu yönünde görüş bildiren Mükellef (11), ceza almamasının nedenini iyi bir muhasebe meslek mensubuyla çalışıyor olmasından kaynaklandığını ayrıca ceza almadığı içinde cezaların miktar itibariyle fazla olup olmadığı konusunda bilgi sahibi olmadığını ancak bu konuyla ilgili çevreden duyduklarını şu ifadelerle açıklamıştır:

\footnotetext{
${ }^{18}$ Mükellef (4), Mükellef (5), Mükellef (6), Mükellef (7), Mükellef (8), Mükellef (9), Mükellef (11).

${ }^{19}$ Mükellef (13), Mükellef (14).

${ }^{20}$ Mükellef (2), Mükellef (10), Mükellef (15).
} 
Mükellef (11): (...) Herhangi bir cezai bir durumumuz olmadı incelemede. (...)

(...) Şimdi mali müşavir tabii size bir yol gösteriyor. Bu yolu izleyin diyor. $\mathrm{O}$ yol tabii siz bu yoldan dışarı da çıkabilirsiniz paralel de gidebilirsiniz o yola ya da zikzak da çizebilirsiniz o yolda. O yolun üzerinden de gidebilirsiniz. Şimdi doğru olan bu, bu yoldan gideceksin diyor. Farklı yollara saparsan diyor ceza işlemleri uygulanabilir bir denetim sırasında diyor. Biz de hiç yolumuzu saptırmadan o söylenmiş olan yolda ilerlemeye çalışıyoruz. (...)

(...) Ceza almadığım içinde tam da bilmiyorum açıkçası hani cezai yaptırımların ne kadar olduğunu. Ama mutlaka, çünkü zaman zaman duyduğum kadarıyla çevremizdeki insanlardan ceza alanlar, cezai yaptırımlarla karşılaşanlar yüklü miktarda ceza ödediklerini söylüyorlar. (...) (04.08.2017)

Diğer taraftan vergi cezalarının caydırıcı olmadığı yönünde görüş bildiren Mükellef (13) ise, devletin mükelleflere korku aşılamaktan ziyade güven ortamının oluşmasını sağlaması gerektiğini güzel bir örnek vererek şu şekilde açıklamıştır:

Mükellef (13): (...) Cezayla bir mesele hallolmuyor. Yani yine o bilinçlendirme lazım yani bizim kendimize, ben size bir șey anlatayım. Allah rahmet eylesin lisede öğretmenimiz vardı. Kulakları sağırdı tamamen sağırdı ama kulaklık takıyordu. Edebiyat dersimize geliyordu. Biz Fen bölümündeydik çok önemli değildi ama ilk imtihanı da o yaptı bize liseye başladığımızda. Dedi ki evlatlarım dedi bu kulaklık benim kimyamı çok bozuyor dedi. Şimdi ben size soruları soracağım, o zaman hep klasik sorular vardı. Yazdırdı işte soruları. Şimdi dedi bu kulaklığı çıkarıyorum evlatlarım dedi. Beni suiistimal etmeyeceğinizi çok iyi biliyorum dedi. İçimizde bir kişi suiistimal etti 40, 45 kişilik sınıfta. Hiç kimse şey yapmadı bakın. Bunu verdiğiniz zaman o işte en büyük sermaye bu olacak yani. Var ya benim aldığım öğretmenlerim içinde en büyük ders buydu. Bana adamsın diyor sana güveniyorum diyor insansın diyor. (...) (04.08.2017)

Elde edilen bulgular;

- Vergi mükelleflerinin büyük meblağ içeren vergi cezası almadıklarını,

- Bunun nedenini iyi bir meslek mensubuna sahip olmasına bağlayan vergi mükelleflerinin olduğunu,

- Bazı mükelleflerin vergi cezalarının caydırıcılık yönünün olduğunu belirttiği,

- Bazılarının vergi cezalarının caydırıcılık yönünün olmadığını belirttiği ve

- Devletin vergi mükelleflerine korku aşılamaktan ziyade güven ortamı oluşması için çaba sarf etmesi gerektiğini,

- Bazı mükellefler için ise vergi cezalarının caydırıcılık yönünün kişiden kişiye göre değişebileceğinin belirtildiği görülmektedir.

Sonuç olarak mükelleflerin büyük meblağ içeren cezalara maruz kalmadıkları görülmüştür. Ayrıca mükellefler cezaya maruz kalmadıkları için cezaların miktar itibariyle fazla olup olmadığı konusunda çok fazla bilgi sahibi olmadıklarını belirtmişlerdir. Ancak çevreden cezaların fazla olduğu yönünde duyumlar aldığını söyleyen mükellefler de bulunmaktadır. Vergi cezalarının caydırıcı olup olmadığı konusunda ise görüş farklılığı bulunmakla birlikte, caydırıcı olduğu yönünde görüş bildiren mükelleflerin sayıca fazla olduğu görülmektedir. Vergi 
cezalarının caydırıcılık yönünün olmadığını belirten mükellefler ise devletin korku aşılamaktan ziyade güven ortamının oluşması için çaba sarf etmesi gerektiğini ifade etmiştir.

\section{Değerlendirme ve Sonuç}

Muhasebe meslek mensupları ile mükelleflerin karşılaştıkları sorunlar karşısında muhasebe meslek mensuplarının bu sorun karşısındaki tutumu ve çözüm önerilerinin vergi uyumu üzerindeki etkisi önemlidir. Bu durumun tespitine ilişkin değerlendirmeler şu şekildedir.

Mevzuatın açık olmaması her ne kadar vergisel sorunlara sebebiyet verse de temel sıkıntının mükelleften kaynaklandığı sonucuna ulaşılmıştır. Mükelleflerin bilgisizliğinden ya da vergi kaçırma amacıyla hareket ettiğinden vergisel sorunlar ortaya çıkmaktadır. Mükellef burada muhasebe meslek mensubu sürece dâhil olmadan önce tüm yasa dışı işlemleri yapabilmektedir. Muhasebe meslek mensubu ücretini mükelleften aldığı için yapılan bu işlemleri bir şekilde yasaya uydurabilmektedir. Mükellef zaten bunu beklemekte, ücret karşıllı̆ı alacağı hizmetin bunu kapsadığ düşüncesindedir.

Elde edilen bulgular her ne kadar muhasebe meslek mensuplarının bir sorun ortaya çıkmadan mükellefleri vergi ödevlerinin olması gerektiği gibi yapılması noktasında yönlendirdikleri ve uyarıda bulundukları yönünde ise de burada mükelleflerin muhasebe meslek mensuplarının tavsiyelerini ciddiye almadıkları tespit edilmiştir. Mükellefler ancak bir cezaya maruz kaldığında ya da denetime girdiğinde bu durumun ciddiyetini anlamaktadırlar.

Vergi uyumunun sağlanmasında vergi cezalarının etkinliği ise tartışmalıdır. Vergi kaçırma amacıyla hareket eden mükellef grubu için cezalar etkin değildir. Çünkü bu mükellefler her türlü olası durumu düşünerek hareket etmektedirler. Diğer taraftan vergisini düzenli olarak ödeyen mükellef grubunda mevcut sistemde yer alan birtakım uygulamaların dürüst mükellefleri cezalandırdığı düşüncesi hâkimdir.

Mükellefler vergisel bir sorun karşısında muhasebe meslek mensuplarının kendilerine destek olduklarını ancak sorun vergi mahkemesine taşınacaksa bu noktada avukata ihtiyaç duyduklarını belirtmişlerdir. Muhasebe meslek mensuplarının buradaki fonksiyonu vergi uyumu açısından önem teşkil etmektedir. Daha sonra sorun oluşturabilecek durumlara karşı mükellefleri uyaran, sorunla karşı karşıya kalındığında ise onları yönlendiren muhasebe meslek mensuplarının vergi uyumunun sağlanmasında olumlu katkıları olabilecektir. Diğer taraftan sorun karşında çözüm bulan muhasebe meslek mensuplarının olması mükellefler de bir sorun çıktığında muhasebe meslek mensubumuz nasıl olsa halleder şeklinde bir algının gelişmesine de neden olabilir. Bu durum ise vergi uyumunun sağlanmasını zorlaştıracaktır.

Mükelleflerin karşılaştıkları sorunlar karşısında muhasebe meslek mensuplarının fonksiyonu bilinçli mükellef ve vergi kaçırma güdüsüyle hareket eden mükellefe göre değişiklik göstermektedir. Bilinçli mükellef ile çalışan muhasebe meslek mensubunun sorun karşısında sunduğu çözüm önerileri mükellefleri vergi ödeme konusunda daha istekli hale getirebilir. Diğer taraftan vergi kaçırma güdüsüyle hareket eden mükellef üzerinde muhasebe meslek 
mensubunun bir fonksiyonu olamamakta dolayısıyla vergi ödeme konusunda zaten isteksiz olan bu mükellef vergi karşısında aynı davranışını sürdürmeye devam etmektedir.

Sonuç olarak vergi uyumunun sağlanması için, vergi ile ilişkili kişi ve kurumlar özelinde derinlemesine araştırmalar yapılmalı ve bu araştırma sonuçlarına yeterince itibar edilmelidir.

\section{Kaynakça}

Creswell, J. W. (2007). Educational Research: Planning, Conducting, and Evaluating Quantitative, Prentice Hall Upper Saddle River, NJ.

Deran, A. \& Beller, B. (2017). Muhasebe Meslek Mensuplarının Karşılaştıkları Sorunlar ve Bağlı Bulundukları Meslek Odasından Beklentileri Üzerine Bir Araştırma. Muhasebe ve Denetime Bakış, 16(50), 37-56.

Gökgöz, A. \& Zeytin, M. (2012). Muhasebe Meslek Mensuplarının Mesleki Faaliyetlerinde Karşılaştıkları Sorunlar ve Beklentileri: Bilecik ve Yalova İlleri Uygulaması. Süleyman Demirel Üniversitesi İktisadi ve İdari Bilimler Fakültesi Dergisi, 17(1), 477-493.

James, S. \& Alley, C. (2002). Tax Compliance, Self-Assessment and Tax Administration. Journal of Finance and Management in Public Services, 2(2), 27-42.

Kalaycı, Ş. \& Tekşen, Ö. (2006). Muhasebecilik Mesleğinde Karşılaşılan Sorunlar ve Çözüm Önerileri: Isparta İl Merkezi Uygulaması. Muhasebe ve Finansman Dergisi, 31, 90-101.

Merriam, S. B. (1998). Qualitative Research and Case Study Applications in Education, San Francisco: Jossey-Bass.

Patton, M. Q. (1987). How To Use Qualitative Methods in Evaluation, CA: Sage.

Tuğay, O. \& Tekşen, Ö. (2014). Muhasebe Meslek Mensuplarının Sorunları: Burdur İlinde Bir Araştırma. Süleyman Demirel Üniversitesi İktisadi ve İdari Bilimler Fakültesi Dergisi, 19(1), 223-232.

Yıldırım, A. \& Şimşek, H. (2013). Sosyal Bilimlerde Nitel Araştırma Yöntemleri, Ankara: Seçkin. 